\title{
KOMPARASI SUCCESFUL AGING DAN SELF EFFICACY LANSIA YANG TINGGAL BERSAMA KELUARGA DENGAN LANSIA YANG TINGGAL DI PANTI WERDHA
}

\section{Comparison Of Succesful Aging And Self Efficacy Elderly Who Lived With Family and Elderly Lived In Nursing Home}

\author{
Nanik Dwi Astutik ${ }^{1}$; Wisoedhanie Widi Anugrahanti ${ }^{2}$; Yafet Pradikatama Pradikatama ${ }^{3}$ \\ 1. Prodi D3 Keperawatan (STIKes Panti Waluya Malang, nanikd79@gmail.com) \\ 2. Prodi D3 Keperawatan (STIKes Panti Waluya Malang) \\ 3. Prodi S1 Keperawatan (STIKes Panti Waluya Malang)
}

\begin{abstract}
ABSTRAK
Latar belakang: Peningkatan dari pertumbuhan lanjut usia secara kuantitas belum diikuti peningkatan kualitas hidup. Successful aging atau menjadi tua yang sukses adalah tujuan dari perkembangan tahap akhir lansia. Selain aspek tersebut self efficacy pada lansia diperlukan agar lansia mempunyai keyakinan dan kepercayaan diri dalam kegiatan sehari-hari dan untuk mencapai successful aging.

Tujuan: Tujuan penelitian ini untuk mengetahui komparasi successful aging dan self efficacy lansia yang tinggal bersama keluarga dan tinggal di panti werdha.

Metode : Penelitian ini bersifat kuantitatif. Desain penelitian kuantitatif komparatif dengan melibatkan 60 responden terdiri dari 31 lansia yang tinggal bersama keluarga dan 29 lansia yang tinggal di Panti. Alat ukur / instrumen penelitian menggunakan penilaian successful aging dan self efficacy. Analisis data menggunakan uji Mann-Whitney.

Hasil: Hasil analisis bahwa sebagian besar lansia yang tinggal bersama keluarga memiliki succesful aging dan self efficacy yang baik. Perbedaan succesful aging menunjukkan nilai Assymp. sig (2-tailed) sebesar 0,025 <0,05, artinya ada perbedaan antara succesful aging pada lansia yang tinggal bersama keluarga dengan lansia yang tinggal di panti dan hasil analisis Perbedaan self efficacy menunjukkan nilai Assymp. sig (2-tailed) sebesar 0,021 <0,05, artinya ada perbedaan antara self efficacy pada lansia yang tinggal bersama keluarga dengan lansia yang tinggal di panti.
\end{abstract}

Kesimpulan: Sehingga dapat disimpulkan bahwa ada perbedaan successful aging dan self efficacy pada lansia yang tinggal bersama keluarga dan tinggal di panti werdha. Adanya perbedaan ini disebabkan karena lansia yang sukses cenderung memiliki dukungan sosial terutama dari keluarga baik emosional maupun material yang bisa membantu mereka dalam menghadapi setiap perubahan-perubahan yang mereka alami dengan baik, sehingga setiap lansia dapat mencapai successful agingnya.

Kata Kunci: successful aging; self efficacy; lansia bersama keluarga; lansia di panti.

\section{Abstract}

Backgraund: Increasing elderly growth has not been followed by improved quality of life. Successful aging or becoming old successfully is the goal of developing the final stage in the elderly. In addition to these aspects of self efficacy in the elderly is necessary for the elderly to have confidence and confidence in the daily activities and for the achievement of successful aging.

Aim : The purpose of this research is to know the comparison of successful aging and self efficacy in elderly who live with family and stay in the home Werdha.

Method: This research is quantitative. Comparative quantitative research design involving 60 respondents consisted of 31 elderly living with families and 29 elderly living in the 
orphanage. Measuring instruments use successful aging and self efficacy assessments. Data analysis using the Mann-Whitney test.

Results :The analysis results of succesful aging differences indicate the value of Assymp.sig (2-tailed) amounted to $0.025<0.05$, meaning there is a difference between succesful aging in elderly living with families with elderly living in the orphanage and the results of the self efficacy differences indicate the value of Assymp. sig (2-tailed) amounting to $0.021<0.05$, meaning there is a difference between self efficacy in elderly living with families with elderly living in the orphanage.

Conclusion : So it can be concluded that there is a difference of successful aging and self efficacy in the elderly who live with the family and stay in the home Werdha. The difference is because the successful elderly tend to have social support especially from both emotional and material families who can help them in the face of any changes they experience. Well, so that every elderly can achieve successful Aging.

Keywords: successful aging; self efficac; elderly who live with family; stay in the home Werdha

\section{PENDAHULUAN}

Masa lanjut usia / lansia merupakan tahap lanjut dari suatu proses kehidupan atau masa terakhir perkembangan dalam hidup manusia yang ditandai oleh penurunan kemampuan tubuh untuk beradaptasi dengan stres lingkungan dan penurunan daya kemampuan untuk hidup serta kepekaan secara individual (Efendi dkk, 2009). Menurut Undang-undang No. 13 Ayat 12 Tahun 1998 dinyatakan bahwa yang dimaksud dengan lanjut usia adalah seorang yang berumur 60 tahun ke atas. Klasifikasi umur lansia menurut World Health Organization (WHO) dibagi menjadi 4 yaitu umur 45 sampai 59 tahun (middle age), 60 sampai 74 tahun (elderly), 75 sampai 90 tahun (old) dan usia di atas 90 tahun (very old).

Meningkatnya taraf hidup dan taraf kesehatan mengakibatkan pertumbuhan penduduk lansia hampir di setiap negara meningkat dan pertumbuhan penduduk usia 60 tahun keatas tumbuh lebih pesat dari kelompok umur lainnya. Berdasarkan data Pusat Data dan Informasi Kementerian Kesehatan Republik Indonesia, diprediksi jumlah penduduk lansia tahun 2020 adalah sebesar 27,08 juta; tahun 2025 sebesar 33,69 juta; tahun 2030 sebesar 40,95 juta; serta tahun 2035 sebesar 48,19 juta. Peningkatan kuantitas lanjut usia belum tentu diikuti dengan peningkatan kualitas hidup. Di Indonesia, kualitas hidup lansia masih dianggap rendah, hal ini dapat dilihat dari berbagai indikator antara lain banyak lansia yang memiliki ketergantungan terhadap anak atau keluarga yang lain karena lansia tersebut kurang produktif.

Departemen sosial juga menjelaskan program jaminan sosial dari pemerintah untuk lansia masih terbatas, oleh karena itu bantuan dari anggota keluarga lain yang masih produktif (seperti anak, keponakan, cucu atau anggota keluarga yang lain) akan terus diperlukan, terutama dalam hal perumahan dan pemenuhan kebutuhan standar hidup, hal tersebut menunjukan bahwa masih banyak lansia di Indonesia yang belum mencapai successful 
agingnya (Kemensos RI, 2012). Hasil penelitian Suardana, dkk (2014) menyatakan bahwa lansia yang memiliki dukungan keluarga baik memiliki kualitas hidup yang baik. Lansia memilih tinggal bersama dengan anak karena menginginkan kasih sayang, perhatian dan kehangatan serta menganggap hal tersebut sebagai kewajiban yang wajar dari anak.

Namun, ketika anak dan keluarganya menjadi beban bagi lanjut usia, atau sebaliknya lansia dianggap sebagai beban bagi keluarga maka akan memberikan kesan tersendiri bagi lanjut usia. Hal tersebut sesuai dengan teori yang diungkapkan oleh Papalia et al (2008), orang tua cenderung menjadi tertekan apabila anak mereka memiliki masalah, misalnya masalah terkait ketergantungan keuangan, yang dianggap sebagai sinyal kegagalan mereka atau anakanaknya sudah tidak bisa memberikan perhatian penuh karena kesibukannya. Menurut Butler (dalam Hurlock, 2004) menyatakan bahwa lanjut usia seringkali secara tidak proporsional menjadi subjek bagi masalah emosional dan mental yang berat, seringkali lansia dimasukan ke panti jompo baik atas inisiatif keluarga maupun lansia itu sendiri.

Lansia yang dimasukkan ke panti jompo pada awalnya akan merasa cemas dan tidak terima dengan perlakuan dari anak-anaknya dan ini akan membuat lanjut usia tidak bisa meraih successful aging (optimal aging). Meskipun ada juga lansia yang hidup di panti jompo bisa meraih successful aging (optimal aging) dari kehidupannya sekarang dikarenakan bertemu dengan sesama lansia yang lain dan mampu bergaul dengan teman-teman barunya yang dianggap bisa memberikan dukungan, karena salah satu faktor terpenting yang harus dimiliki oleh lansia agar dapat mencapai succesfull aging adalah keyakinan tentang sejauh mana lansia tersebut memperkirakan kemampuan dirinya dalam melakukan dan menyelesaikan tugas yang diperlukan untuk mencapai suatu hasil tertentu

Menurut penelitian Adrianisah \& Septiningsih (2013) bahwa faktor yang dapat mempengaruhi pencapaian successful aging pada lansia yaitu adalah resiliensi dan sikap yang lebih optimis pada dalam menghadapi tantangan semasa hidupnya. Berdasarkan Sarafino \& Smith (2011) hal yang paling terpenting yang harus dimiliki oleh individu untuk dapat melaksanakan perilaku sehat adalah self-efficacy. Seorang individu memerlukan cukup self efficacy untuk melaksanakan perubahan dalam hidupnya, tanpa self-efficacy, motivasi mereka untuk berubah akan terhambat. Menurut penelitian Rahmawati \& Saldiyah S. (2016) bahwa faktor yang mempengaruhi kesuksesan di masa lanjut usia adalah faktor kesehatan fisik, aktivitas, psikologis, sosial dan faktor religiusitas, dimana tercapainya succesfull aging terletak pada semua usaha yang dilakukan oleh lansia untuk mencapai kesuksesan yang didasari oleh faktor di atas. 


\section{METODE}

Desain penelitian ini menggunakan desain penelitian kuantitatif komparatif dengan sampel sejumlah 60 responden lansia yang terdiri dari 31 lansia yang tinggal bersama keluarga dan 29 lansia yang tinggal di Panti Werda yang diambil menggunakan purposive sampling. Alat ukur dalam penelitian ini menggunakan penilaian successful aging untuk mengetahui pencapaian successful aging lansia dan penilaian self efficacy untuk mengetahui keyakinan lansia terhadap kemampuan dirinya. Analisis data menggunakan uji Mann-Whitney. Hasil analisis Perbedaan Succesful Aging menunjukkan nilai Assymp. sig (2-tailed) sebesar 0,025 < 0,05 , artinya ada perbedaan yang signifikan antara succesful aging pada lansia yang tinggal dirumah dengan lansia yang tinggal di Panti Hasil analisis Perbedaan Self Efficacy menunjukkan nilai Assymp. sig (2-tailed) sebesar 0,021 <0,05, artinya ada perbedaan yang signifikan antara Self Efficacy pada lansia yang tinggal dirumah dengan lansia yang tinggal di Panti.. Sehingga dapat disimpulkan bahwa ada perbedaan successful aging dan self efficacy pada lansia yang tinggal bersama keluarga dan tinggal di Panti Werdha.

\section{HASIL}

Berdasarkan table 1 diatas dapat diketahui bahwa proporsi lansia yang tinggal bersama keluarga sebagian besar berusia $\geq 65$ Tahun $(51,6 \%)$ dan proporsi lansia yang tinggal bersama keluarga hampir seluruhnya berusia $\geq 65$ Tahun $(89,7 \%)$. Proporsi lansia yang tinggal bersama keluarga hampir seluruhnya perempuan $(96,8 \%)$, sedangkan proporsi lansia yang tinggal di panti sebagian besar laki-laki $(62,1 \%)$. Proporsi lansia yang tinggal di rumah hampir seluruhnya berpendidikan rendah $(80,6 \%)$ dan proporsi lansia yang tinggal di panti sebagian besar berpendidikan rendah (51,7\%). Proporsi lansia yang tinggal bersama keluarga hampir setengahnya tidak berkerja $(45,2 \%)$ dan proporsi lansia yang tinggal di panti sebagian besar bekerja sebagai pegawai swasta $(51,7 \%)$.

Hasil analisis Perbedaan Kemampuan dalam Penyesuaian Diri pada lansia yang tinggal dirumah dengan lansia yang tinggal di panti menunjukkan bahwa nilai Assymp. sig (2-tailed) sebesar 0,957 >0,05, artinya tidak ada perbedaanyang signifikan antara Kemampuan dalam Penyesuaian Diri pada lansia yang tinggal dirumah dengan lansia yang tinggal di panti (tabel 2). Pada tabel diatas juga menunjukkan bahwa lansia yang tinggal dirumah tidak memberikan perbedaan nilai rata-rata yang signifikan dengan lansia yang tinggal di panti. 
Hasil analisis Perbedaan dalam hal penerimaan segala perubahan dan kemunduran yang dialami pada lansia yang tinggal dirumah dengan lansia yang tinggal di panti menunjukkan bahwa nilai Assymp. sig (2-tailed) sebesar 0,011<0,05, artinya ada perbedaan yang signifikan antara penerimaan segala perubahan dan kemunduran yang dialami pada lansia yang tinggal dirumah dengan lansia yang tinggal di panti. Pada tabel diatas juga menunjukkan bahwa lansia yang tinggal dirumah memberikan rata-rata nilai sucesful aging yang lebih tinggi daripada lansia yang tinggal di panti.

Hasil analisis Perbedaan (tabel 4) penghargaan dan perlakuan dari lingkungan yang diterima pada lansia yang tinggal dirumah dengan lansia yang tinggal di panti menunjukkan bahwa nilai Assymp. sig (2-tailed) sebesar 0,008 < 0,05, artinya ada perbedaan yang signifikan antara penghargaan dan perlakuan dari lingkungan yang diterima pada lansia yang tinggal dirumah dengan lansia yang tinggal di panti. Pada tabel diatas juga menunjukkan bahwa lansia yang tinggal dirumah memberikan rata-rata nilai penghargaan dan perlakuan dari lingkungan yang diterima lebih tinggi daripada lansia yang tinggal di panti.

Hasil analisis (tabel 5) perbedaan penghargaan hak-hak lansia yang diterima pada lansia yang tinggal dirumah dengan lansia yang tinggal di panti menunjukkan bahwa nilai Assymp. Sig (2-tailed) sebesar 0,040 <0,05, artinya ada perbedaan yang signifikan antara penghargaan hak-hak lansia yang diterima pada lansia yang tinggal dirumah dengan lansia yang tinggal di panti. Pada tabel diatas juga menunjukkan bahwa lansia yang tinggal dirumah memberikan rata-rata nilai penghargaan hak-hak lansia yang diterima lebih tinggi daripada lansia yang tinggal di panti.

Hasil analisis perbedaan (tabel 6) ketersediaan media untuk akutualisasi potensi dan kemampuan pada lansia yang tinggal dirumah dengan lansia yang tinggal di panti menunjukkan bahwa nilai Assymp. sig (2-tailed) sebesar 0,007 <0,05, artinya ada perbedaan yang signifikan antara ketersediaan media untuk akutualisasi potensi dan kemampuan pada lansia yang tinggal dirumah dengan lansia yang tinggal di panti. Pada tabel diatas juga menunjukkan bahwa lansia yang tinggal dirumah memberikan rata-rata ketersediaan media untuk akutualisasi potensi dan kemampuan lebih tinggi daripada lansia yang tinggal di panti.

Hasil analisis Perbedaan Succesful Aging pada lansia yang tinggal dirumah dengan lansia yang tinggal di panti menunjukkan bahwa nilai Assymp. sig (2-tailed) sebesar 0,025 < 0,05, artinya ada perbedaan yang signifikan antara succesful aging pada 
lansia yang tinggal dirumah dengan lansia yang tinggal di panti. Pada tabel diatas juga menunjukkan bahwa lansia yang tinggal dirumah memberikan rata-rata nilai sucesful aging yang lebih tinggi daripada lansia yang tinggal di panti.

Hasil analisis (tabel 8) Perbedaan Self Efficacy pada lansia yang tinggal dirumah dengan lansia yang tinggal di panti menunjukkan bahwa nilai Assymp. sig (2-tailed) sebesar 0,021 $<0,05$, artinya ada perbedaan yang signifikan antara Self Efficacy pada lansia yang tinggal dirumah dengan lansia yang tinggal di panti. Pada tabel diatas juga menunjukkan bahwa lansia yang tinggal dirumah memberikan rata-rata nilai self efficacy yang lebih tinggi daripada lansia yang tinggal di panti.

Hasil uji analisis statistik (tabel 9) menunjukkan bahwa nilai Assymp. sig (2-tailed) sebesar 0,025 $<0,05$, artinya ada perbedaan yang signifikan antara succesful aging pada lansia yang tinggal dirumah dengan lansia yang tinggal di panti dan nilai Assymp. sig (2tailed) sebesar 0,021 < 0,05, artinya ada perbedaan yang signifikan antara Self Efficacy pada lansia yang tinggal bersama keluarga dengan lansia yang tinggal di panti.

\section{PEMBAHASAN}

Tabel 7 menggambarkan hasil analisis perbedaan succesful aging pada lansia yang tinggal dirumah dengan lansia yang tinggal di panti menunjukkan bahwa ada perbedaan yang signifikan antara succesful aging pada lansia yang tinggal bersama keluarga dengan lansia yang tinggal di panti dimana lansia yang tinggal bersama keluarga memberikan rata-rata nilai sucesful aging yang lebih tinggi daripada lansia yang tinggal di panti. Pada tabel 9 juga menunjukkan hasil analisis perbedaan self ffficacy pada lansia yang tinggal bersama keluarga dengan lansia yang tinggal di panti menunjukkan bahwa ada perbedaan yang signifikan antara selfffficacy pada lansia yang tinggal bersama keluarga dengan lansia yang tinggal di panti dimana lansia yang tinggal bersama keluarga memberikan rata-rata nilai self efficacy yang lebih tinggi daripada lansia yang tinggal di panti. Adanya perbedaan ini disebabkan karena lansia yang sukses (successful aging) dan memiliki self efficacy yang optimal cenderung memiliki dukungan sosial terutama dari keluarga baik emosional maupun material yang dapat membantu mereka dalam menghadapi setiap perubahan-perubahan yang mereka alami dengan baik, sehingga setiap lansia dapat mencapai successful agingnya. 


\section{KESIMPULAN}

Dari hasil penelitian ini dapat disimpulkan bahwa ada perbedaan succesful aging dan self efficacy dimana lansia yang tinggal berasma keluarga memiliki sucesful aging dan self efficacy yang lebih tinggi daripada lansia yang tinggal di Panti.

\section{DAFTAR PUSTAKA}

Adrianingsih dan Septiningsih D. (2013). Successful Aging (studi tentang lanjut usia yang anak dan keluarganya tinggal bersama). Jurnal Psycho Idea, Tahun 11.No.1, Februari 2013 ISSN 1693-1076. Fakultas Psikologi Universitas Muhammadiyah Purwokerto

Badan Pusat Statistik (BPS). 2013. Sensus Penduduk 2010.

Bandiyah Siti (2009) .Lanjut Usia dan Keperawatan Gerontik. Yogjakarta:Nuha Medika

Bandura, Albert. (2001). Self Efficacy. New York: W.H. Freeman and Company

Effendi, F \& Makhfudli. 2009. Keperawatan Kesehatan Komunitas: Teori dan Praktek Dalam Keperawatan. Jakarta: Salemba medika.

Hurlock. B .2004. Psikologi Perkembangan: Suatu Pendekatan Sepanjang Rentang Kehidupan. Jakarta: Erlangga

Kementrian Kesehatan Republik Indonesia Tahun 2013. World Population Prospective.2010.Jakarta.

Nugroho. 2010. Keperawatan Gerontik dan Geriatrik. Jakarta: Penerbit Buku Kedokteran: EGC.

Rahmawati F. \& Saldiyah S. (2016). Makna Sukses Di Masa Lanjut. Jurnal Ilmiah Psikologi, Juni 2016, Vol.3, No.1.

Suardana W, Saraswati N., Wiratni M. (2014). Hubungan Dukungan Keluarga Dan Kualitas Hidup Lansia Hipertensi. Jurusan Keperawatan Politeknik Kesehatan Denpasar.

Sadock B. J., Sadock V. A. 2010. Kaplan \& Sadock's Concise Text Book Of Clinical Psychiatry, 2Nd ed. Diterjemahkan Oleh Profitasari dan TM Nisa dengan Judul Kaplan \& Sadock Buku Ajar Psikiatri, Ed 2. Jakarta : EGC

Sarafino, E.P. (2002). Health psychology biopsychological interaction. USA: John Wiley \& Sons.

http://Kemsos.go.id/read/detail/2018/04/03/10505134/Penduduk Berusia lanjut di indonesia.htm diunduh 03/04/2018. 


\section{LAMPIRAN}

Tabel 1: Karakterisitik umum responden

\begin{tabular}{|c|c|c|c|c|c|}
\hline \multicolumn{2}{|c|}{ Karakteristik Variabel } & \multicolumn{2}{|c|}{$\begin{array}{l}\text { Lansia yang } \\
\text { tinggal bersama } \\
\text { keluarga } \\
\end{array}$} & \multicolumn{2}{|c|}{$\begin{array}{l}\text { Lansia yang } \\
\text { tinggal di Panti }\end{array}$} \\
\hline & & $\mathrm{n}$ & $(\%)$ & $\mathrm{n}$ & $(\%)$ \\
\hline \multirow[t]{2}{*}{ Usia } & - <65 Tahun & 15 & 48,4 & 3 & 10,3 \\
\hline & - $\quad \geq 65$ Tahun & 16 & 51,6 & 26 & 89,7 \\
\hline Jenis & - Perempuan & 30 & 96,8 & 11 & 37,9 \\
\hline $\begin{array}{l}\text { Kelami } \\
\mathrm{n}\end{array}$ & - Laki-Laki & 1 & 3,2 & 18 & 62,1 \\
\hline \multirow{4}{*}{$\begin{array}{l}\text { Pendidi } \\
\text { kan }\end{array}$} & - Pendidikan & 25 & 80,6 & 15 & 51,7 \\
\hline & Rendah & & 12,9 & 12 & 41,4 \\
\hline & $\begin{array}{l}\text { - Pendidikan } \\
\text { Menengah }\end{array}$ & 4 & & & \\
\hline & $\begin{array}{l}\text { - Pendidikan } \\
\text { - }\end{array}$ & 2 & 6,5 & 2 & 6,9 \\
\hline \multirow{6}{*}{$\begin{array}{l}\text { Pekerja } \\
\text { an }\end{array}$} & - Tidak & 14 & 45,2 & 4 & 13,8 \\
\hline & $\begin{array}{l}\text { Bekerja } \\
\text { - } \quad \text { IRT }\end{array}$ & 9 & 29,0 & 1 & 3,4 \\
\hline & - Wiraswasta & 8 & 25,8 & 7 & 24,1 \\
\hline & - Swasta & 0 & 0 & 15 & 51,7 \\
\hline & - PNS & 0 & 0 & 1 & 3,4 \\
\hline & - Lain-lain & 0 & 0 & 1 & 3,4 \\
\hline
\end{tabular}

Tabel 2: Perbedaan Kemampuan dalam Penyesuaian Diri pada Lansia yang tinggal dirumah dan Lansia yang tinggal di panti.

\begin{tabular}{|c|c|c|c|}
\hline Variabel & $\mathbf{N}$ & Mean & $\begin{array}{c}\text { Assymp. Sig } \\
\text { (2-Tailed) }\end{array}$ \\
\hline $\begin{array}{l}\text { Lansia yang } \\
\text { tinggal } \\
\text { dirumah }\end{array}$ & 31 & 30,39 & \multirow[t]{2}{*}{0,957} \\
\hline $\begin{array}{l}\text { Lansia yang } \\
\text { tinggal dipanti }\end{array}$ & 29 & 30,62 & \\
\hline
\end{tabular}

Tabel 3: Perbedaan penerimaan segala perubahan dan kemunduran yang dialami pada Lansia yang tinggal dirumah dan Lansia yang tinggal di panti

\begin{tabular}{lccc}
\hline Variabel & N & Mean & $\begin{array}{c}\text { Assymp. Sig } \\
\text { (2-Tailed) }\end{array}$ \\
\cline { 1 - 2 } $\begin{array}{l}\text { Lansia yang } \\
\text { tinggal } \\
\text { dirumah }\end{array}$ & 31 & 35,82 & \\
\cline { 1 - 2 } $\begin{array}{l}\text { Lansia yang } \\
\text { tinggal dipanti }\end{array}$ & 29 & 24,81 & 0,011 \\
\hline
\end{tabular}

Tabel 4: Perbedaan penghargaan dan perlakuan dari lingkungan yang diterima pada Lansia yang tinggal dirumah dan Lansia yang tinggal di panti

\begin{tabular}{llcc}
\hline Variabel & N & Mean & $\begin{array}{c}\text { Assymp. Sig } \\
\text { (2-Tailed) }\end{array}$ \\
\cline { 1 - 2 } $\begin{array}{l}\text { Lansia yang } \\
\text { tinggal } \\
\text { dirumah }\end{array}$ & 31 & 34,65 & \\
\cline { 1 - 2 } $\begin{array}{l}\text { Lansia yang } \\
\text { tinggal } \\
\text { dipanti }\end{array}$ & 29 & 26,07 & 0,040 \\
\hline
\end{tabular}

Tabel 5: Perbedaan penghargaan hak-hak lansia yang diterima pada Lansia yang tinggal dirumah dan Lansia yang tinggal di panti.

\begin{tabular}{lccc}
\hline Variabel & N & Mean & $\begin{array}{c}\text { Assymp. } \\
\text { Sig (2- } \\
\text { Tailed) }\end{array}$ \\
\hline $\begin{array}{l}\text { Lansia yang } \\
\text { tinggal } \\
\text { dirumah }\end{array}$ & 31 & 35,82 & \\
\cline { 1 - 2 } $\begin{array}{l}\text { Lansia yang } \\
\text { tinggal dipanti }\end{array}$ & 29 & 24,81 & 0,008 \\
\hline
\end{tabular}

Tabel 6: Perbedaan ketersediaan media untuk aktualisasi potensi dan kemampuan pada Lansia yang tinggal dirumah dan Lansia yang tinggal dipanti.

\begin{tabular}{|c|c|c|c|}
\hline Variabel & $\mathbf{N}$ & Mean & $\begin{array}{c}\text { Assymp. Sig } \\
\text { (2-Tailed) }\end{array}$ \\
\hline $\begin{array}{l}\text { Lansia yang } \\
\text { tinggal } \\
\text { dirumah }\end{array}$ & 31 & 35,92 & \multirow{2}{*}{0,007} \\
\hline $\begin{array}{l}\text { Lansia yang } \\
\text { tinggal dipanti }\end{array}$ & 29 & 24,71 & \\
\hline
\end{tabular}


Tabel 7: Perbedaan Successful Aging pada Lansia yang tinggal dirumah dan Lansia yang tinggal di panti.

\begin{tabular}{llll}
\hline \multicolumn{1}{c}{ Variabel } & N & Mean & $\begin{array}{c}\text { Assymp. } \\
\text { Sig (2- } \\
\text { Tailed) }\end{array}$ \\
\hline $\begin{array}{llll}\text { Lansia yang } \\
\text { tinggal }\end{array}$ & 31 & 35,37 & \\
$\begin{array}{l}\text { dirumah } \\
\text { Lansia yang } \\
\text { tinggal } \\
\text { dipanti }\end{array}$ & 29 & 25,29 & 0,025 \\
\hline
\end{tabular}

Tabel 8: Perbedaan self efficacy pada Lansia yang tinggal dirumah dan Lansia yang tinggal di panti

\begin{tabular}{lccc}
\hline \multicolumn{1}{c}{ Variabel } & N & Mean & $\begin{array}{c}\text { Assymp.Sig } \\
\text { (2-Tailed) }\end{array}$ \\
\cline { 1 - 2 } $\begin{array}{l}\text { Lansia yang } \\
\text { tinggal dirumah }\end{array}$ & 31 & 35,53 & \\
\cline { 1 - 2 } $\begin{array}{l}\text { Lansia yang } \\
\text { tinggal dipanti }\end{array}$ & 29 & 25,12 & 0,021 \\
\hline
\end{tabular}

Tabel 9: Hasil Analisis Statistik Perbedaan Successful Aging dan self efficacy pada Lansia yang tinggal bersama keluarga dan Lansia yang tinggal di panti.

Test Statistics ${ }^{\mathbf{a}}$
\begin{tabular}{|l|c|c|}
\hline & Successful Aging & Self Efficacy \\
\hline Mann-Whitney U & 298.500 & 293.500 \\
Wilcoxon W & 733.500 & 728.500 \\
Z & -2.245 & -2.315 \\
Asymp. Sig. (2-tailed) & .025 & .021 \\
\hline
\end{tabular}

a. Grouping Variable: RESPONDEN

Ranks

\begin{tabular}{|c|l|c|c|c|}
\hline & \multicolumn{1}{|c|}{ Ranks } & N & Mean & Sum of Ranks \\
\hline \multirow{2}{*}{$\begin{array}{c}\text { Successful } \\
\text { Aging }\end{array}$} & Lansia Tinggal Bersama Keluarga & 31 & 35.37 & 1096.50 \\
& Lansia Tinggal Di Panti & 29 & 25.29 & 733.50 \\
& Total & 60 & & \\
& Lansia Tinggal Bersama Keluarga & 31 & 35.53 & 1101.50 \\
Self Efficacy & Lansia Tinggal Di Panti & 29 & 25.12 & 728.50 \\
& Total & 60 & & \\
\hline \multirow{3}{*}{} & \multicolumn{3}{|l}{} \\
& &
\end{tabular}

